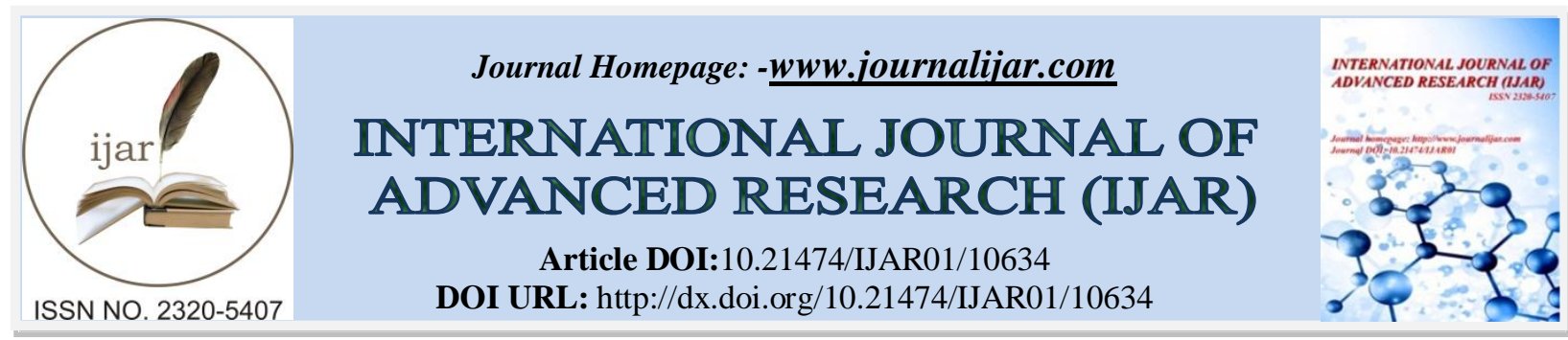

RESEARCH ARTICLE

\title{
THE INFLUENCE OF HUMAN CAPITAL ON SMART CITY IMPLEMENTATION AND SERVICE PERFORMANCE OF THE MAKASSAR CITY GOVERNMENT
}

\author{
Badirun Basir $^{1}$, Nurdin Brasit ${ }^{2}$, Nurdjanah Hamid ${ }^{2}$ and Musran Munizu ${ }^{2}$ \\ 1. Financial Administration Bureau, Hasanuddin University, Indonesia. \\ 2. Department of Management, Faculty of Economics and Business, Hasanudin University, Indonesia.
}

\section{Manuscript Info}

.1........................

Manuscript History

Received: 07 January 2020

Final Accepted: 10 February 2020

Published: March 2020

Key words:-

Human Capital, Smart City Implementation, SERVPERF, SmartPLS

\begin{abstract}
The aims of study are analyze and describe the effect of human capital on the smart city implementation and service performance. To collect data using questionnaires and interviews with 153 respondents, while the analyzed data are 51 respondents. The sampling technique is purposive sampling. Data were analyzed using the Partial Least SquareStructural Equation Modeling (PLS-SEM) technique using the SmartPLS program. The results showed that human capital has a direct, positive and significant effect on the smart city implementation and service performance (SERVPERF). The smart city implementation has a direct, positive and significant effect on service performance (SERVPERF). Human capital has a positive and significant effect on service performance (SERVPERF) through the smart cityimplementation.
\end{abstract}

Copy Right, IJAR, 2020,. All rights reserved.

\section{Introduction:-}

Population movement from rural areas to urban areas has become a common phenomenon that occurs in various parts of the world. United Nations (2015), report that in general, more people live in urban areas than in rural areas. The projection of Indonesian population 2010-2035 issued by the Badan Pusat Statistik (2013), shows that the population of Indonesia continues to growth and in 2020 is predicted to reach more than 56 percent, this number tends to increase and is estimated to reach more than 66 percent in 2035.

Increasing the number of population in urban areas, which is not accompanied by the government's ability in urban planning, will cause various urban problems such as declining quality of public services, decreasing residential land, increasing energy use, garbage accumulation, increasing crime rates, traffic congestion, air pollution and various other problems that must be resolved immediately.

Solving problems and creating a city that is safe and comfortable for its citizens, requires smart solutions with smart city implementation so that it can provide faster, connected, precise and efficient service performance to the community. Ahmadjayadi, et al., (2016), stated that a change was made by the city government by building and changing the mind, life, social and culture of the government apparatus in providing services to the public which is the main task of the public sector.

Smart city is a unique and dynamic city concept, depending on the problems faced by each city. Research by Meijer et al., (2015), shows that smart city implementation not only adopts best practices from other cities, but needs to develop approaches that are appropriate to the situation and conditions of the city itself, broader organizations and

Address:- Financial Administration Bureau, Hasanuddin University, Indonesia. 
strategies, human capital policies, and adaptive information. Initiatives that appear as problem-solving solutions for a city may not necessarily be applied to other cities.

The smart cityimplementation is a top-down and bottom-up policy intervention that requires a shared vision from the citygovernment, specially Makassar City to improve the performance of better public services for the community. The successful smart city implementation on service performance is supported by human capital.

The study of the effect of human capital on smart city implementation and service performance results in various conclusions (research gap).The study of De Noni et al., (2014), shows that the most important attribute in influencing the ability of the city of Milan to attract talent into smart cities is education.Angelidou (2015), shows that smart cities that focus on humans and technological innovation will encourage the development of human capital; and further enhance the ability of people to be creative and participate in the process of solving urban problems.

Study by Krusinskas\&Bruneckiene (2015), introduce urban governance and increase intellectual capital and city competitiveness in Lithuania. Research conducted by Chatterjee (2016) states that sustainable investment in human capital is very important for companies to improve their capabilities and maintain competitive advantage and improve service performance.Kummitha\&Crutzen, (2017) show that technological factors and human capital will create a good synergy in the smart cityimplementation, which can build intelligence and encourage increased public knowledge.

The study is different from previous studies, Klimovsky et al., (2016), that people will not use technology beyond their needs and cause a lack of interest to participate in smart city governance issues. The same study conducted by Ferraris et al., (2018), found that there are different influences on social relations between employees and the community involved in the implementation of smart city. Parent \& Lovelace (2018), produces findings that work involvement has no significant effect on individual abilities.

Research gap that show the effect of human capital on service performance (SERVPERF). In a study by Cooper et al., (1994), the research findings were that higher education levels had a positive effect on service performance. Studies by Wrigth et al., (1995), the results of the study indicate that important characteristics of human capital are education, experience and knowledge that can improve service performance. A study by Lee (2002) developed the e-SERVQUAL model as a tool for evaluating the quality of virtual services including information, transactions, design, communication, and security in evaluation criteria.

Yu \& Hyun (2019), pointed out that the empathy dimension was found to be the most important dimension of service performance (SERVPERF) when flight attendants offered services to aircraft passengers. Furthermore, Le \& Fitzgerald (2014), examined patients in Turkish hospitals that measured patient satisfaction using the SERVPERF scale.

Sharma (2015), the results of the study indicate that the dimensions of service quality (E-S-QUAL), namely: reliability, security, efficiency and responsiveness are the main determinants that influence the willingness to use egovernment services. In addition, demographic variables, namely: age and level of education show a statistically significant effect on using e-government services. Whereas Cho \& Hyun (2016), shows that interaction and aesthetics are positively related to perceived value due to aesthetics and reliability (e-SERVPERF) depending on user satisfaction.

Otherwise, several different studies related to human capital on service performance (SERVPERF). Chi \& Gursoy (2009), shows that employee satisfaction (human capital) has no direct and significant influence on financial performance. There is an indirect relationship between employee satisfaction with financial performance mediated by customer satisfaction.

Costa et al., (2014), revealed that human capital will affect business performance when mediated by intellectual capital. Bae \& Cha (2015), online service delivery has a relatively low influence on service performance. Mahmoud \& Khalifa (2015), which involved Syrian university students as respondents, resulted in the conclusion of unfavorable perceptions about the service performance (SERVPERF) provided by the university. In addition, university support staff were not responsive to provide timely assistance or lack sympathy towards college student. 
Study by Sohail \& Jang (2017), training and development are not determinants of employee satisfaction. Kadasah (2017), conducted research on Saudi telecommunications companies. The results of the study indicate that service performance does not provide satisfaction to customers. Monica \& Ramanaiah (2018), the results of the study showed that actual service (perception) had no significant effect on customer expectations.

Research gap effect of smart city implementation on service performance (SERVPERF). Sharma (2015), suggests that the dimensions of service quality are the main determinants that influence the willingness to use e-government services. In addition, demographic variables show a statistically significant effect on the willingness to use egovernment services. Belanche et al., (2016), empirical studies reveal that personal attitudes and needs, user card ownership, and education level have a positive influence on the use of urban services.

Furthermore Yeh (2017), emphasized that people are willing to accept and use smart city services based on information and communication technology, if the service is designed with innovative concepts that secure privacy and offer high quality services. The findings of Mensah (2017), reinforce the results of this study by suggesting that perceived ease of use, perceived quality of service, and public trust have a positive and significant effect on the willingness to use the municipal service system through e-government. Goi (2017), emphasized that technological innovation has changed the overall effectiveness of services with regard to the implementation of smart cities.

Further study, Chan (2018), shows that the implementation of smart city brings higher brand equity (smart branding) to green and creative themes in the implementation of smart city in Hong Kong city. Research conducted by Pinochet et al., (2018), shows that the smart environment shows the greatest influence on reducing the environmental impact on urban quality, and vice versa smart economy is the dimension giving the lowest influence in smart city implementation.

In contrast, a different study conducted by Riffat et al., (2016), shows the city of the future is focused on the environmental dimension. Paskaleva \& Cooper (2017), found public disappointment at the services provided by the city government in terms of management and public services through smart city.

A study by Siugzdiniene et al., (2017), states that public governance systems cannot be considered as intelligent social systems, where some intelligence characteristics have been well expressed, but smart public governance is not yet part of the culture of the Lithuanian city government. Chouk \& Mani (2019), showed that consumer lifestyle factors reduce consumer resistance to smart cities.

Service quality contributes significantly to the creation of differentiation, positioning, and the competitive strategy of each organization, both manufacturing companies and service providers. Research on service quality by Parasuraman et al., (1988) found five service quality measurement tools, namely: tangibles, reliability, responsiveness, assurance; and empathy, known as the SERVice QUALity (SERVQUAL) model. The SERVQUAL model can be applied to assess service quality in various fields including the government sector.

Cronin \& Taylor (1992), criticized SERVQUAL and proposed an alternative scale called SERVPERF which is an extension of SERVice PERFormance. It covers all dimensions of the SERVQUAL scale, but only assesses perceptions of performance to measure service quality. Efforts to operationalize service quality as a function of multiple linear compensation of performance and importance ratings are also described in the literature Babakus\& Inhofe (2014). However, this model does not exceed SERVQUAL performancewhen applied practically. The only approach that has so far outperformed SERVQUAL is the SERVPERF approach.

This study discusses a field which has not yet been adequately explored is the field of smart city analytic models. Therefore, the purpose of this study is to identify the effect of human capital on the smart cityimplementation. Therefore, researchers are interested in conducting research on the effect of human capital on smart city implementation and service performance (SERVPERF), and with professional human capital support it is expected to improve the service performance (SERVPERF) of city governments, specifically in Makassar City as a world city.

This paper is organized as follows: starting with an introduction, followed by a literature review to build a theoretical model, and generating hypotheses to be tested at the empirical stage of research. Then the methodology 
used for the quantitative research phase. Finally, the results and discussion, as well as the presentation of conclusions.

\section{Literature Review:- Strategy Management}

The birth of strategic management as an academic field can be traced to the 1960s (Furrer et al., 2008). "Strategy and Structure" by Chandler (1962) and "Corporate Strategy" by Ansoff (1965) were the first publications in the field of strategy management. In the first decade of its existence, strategic management solely investigated strategic problems in large established companies (Analoui\&Karami, 2003).

Strategy management is a series of managerial decisions and actions that determine the company's long-term performance. Strategy management includes environmental observation, strategy formulation, strategy implementation, and evaluation and control (Hunger \& Wheelen, 2003).

Strategy management is not only applied in the private sector, but has been applied to the public sector. The implementation of management strategies in the two entities is not much different, it's just that the public sector does not emphasize the goals of the organization in seeking profits, but rather emphasizes the best service to the community (Supanto, 2019).

\section{Resource Based View (RBV)}

Resource Based View (RBV) is recognized as a theory that looks at the ability of a company's internal resources to gain competitive advantage. The company's internal resources consisting of all assets, capabilities, competencies, organizational processes, information, and knowledge can be controlled by the company in order to implement the strategies that have been formulated.

According to Barney (1991), competitive advantage can be obtained if the company controls valuable resources. The value of resources is determined by three factors, namely scarcity, needed (there is demand because it satisfies need), and can be owned or controlled (appropriability). The competitiveness can last as long as the company can protect its resources from changing hands (transfer), unique (rare), valuable (valuable), cannot be imitated (imperfect imitability) and is not replaced (non-substitution).

\section{Theory of Human Capital}

In the 1950s, important factors in production consisted of physical capital, labor, land and management. However, in the early 1960s, studies of accounting economic growth had difficulty explaining the economic growth of the United States in terms of the four traditional factors of production (Schultz, 1961). Inequalities, known as residual factors, are identified as human capital (Schultz, 1961). Thus, capital became multidimensional in the 20th century economic literature and has been expanded to include terms such as financial capital, organizational capital, intellectual capital, human capital, structural capital, relational capital, customer capital, social capital, innovation capital, and process capital (Edvinsson\& Malone, 1997).

Theodore W. Schultz (1961), an American economist who first introduced the theory of human capital (human capital theory). The theory of human capital explains that skills and knowledge are capital that can be invested in the same way as other capital such as machinery and technology and are far superior to financial capital. Furthermore Schultz (1961), education, training and health are forms of investment in human capital, as in physical capital, investment in human capital generates future returns.

Initially, the theory of human capital was broadly developed to estimate the distribution of employee income based on their investment in human capital (Becker, 1964). This theory is often used by organizational researchers, and encourages quite a lot of research (Unger et al., 2011). Individuals, organizations and the wider community get more benefit when resources are used effectively (Schultz, 1961).

According to Edvinsson\& Malone (1997), "human capital is the individual knowledge of experiance, capability, skills, creativity, innovation" (human capital is knowledge, experience, abilities, skills / skills, creativity, and individual innovation). Armstrong (2012), stating that human capital is a person's knowledge, skills and abilities that are used to provide professional services.Felicio et al., (2014), measure human capital through knowledge, experience, expertise, and abilities. 


\section{Resource Dependency Theory}

The Resource Dependence Theory (RDT) was pioneered by Emerson (1962). Emerson identified this theory in the causal relationship between the concept of power and dependency on resources.

Resource dependency theory (RDT) views an organization as an open system that is influenced by its environment. In Rethinking Strategy book, it is explained that the theory of resource dependency has been published since the 1970s and reached its peak through books published by Pfeiffer and Salancik in the 1978s. In the context of organizational theory, this approach is the best thinking as an important correction to structural contingency theory. Where the theory states that companies must adapt the internal structure with external contingencies.

According to Hillman et al., (2009), since its publication, the theory of resource dependency (RDT) has been one of the most influential theories in organizational theory and strategic management. RDT characterizes corporations as open systems, dependent on the external environment (Pfeffer\&Salancik, 1978). RDT theory explains that organizational performance and sustainability depends on its ability to obtain important resources from the external environment.

\section{Citizen-Centric e-governance theory}

Citizen-Centric e-governance theory underlies community empowerment to engage in democratic governance through internet users, technology and other social networks such as Twitter (Reddick, 2011). Therefore, egovernance is able to change the relationship between government and citizens or between citizens and citizens (Reddick, 2011). This provides new virtual public spaces for the public - for example, government-owned social media networks with which they can influence or innovate in political institutions and help the government avoid the use of traditional supply-sides, government provision and public services for more demand with services. Public centered on community satisfaction and participation.

According to Chatfield \& Reddick (2015), smart city implementation is the implementation of a localized bottom-up intervention policy, making new demands on collaborative, participatory, democratic, and forms of social governance that facilitate greater citizen involvement high in problem solving.

\section{Smart City concept}

A city can be defined as "smart" when investments in human capital, social, transportation and information technology drive sustainable economic development and enhance high quality of life, through wise management of natural resources and participatory engagement (Caragliu et al., 2009).

Smart city Implementation according to Ahmadjayadi, et al (2016), dividing smart city is described as follows: (1) Smart Governance: good governance of government bureaucracy, including: administrative servants; services; goods service; good governance; and government policy information systems; (2) Smart Branding (smart regional brand): values, methods and tools of regional development, including: building and developing tourist destinations; building a trading ecosystem platform; investment ecosystem; creative industrial goods and services; and establishing territorial boundaries; building location markers; and provides unique navigation; (3) Smart Economy: building ecosystems that support community economic activities including: leading sectors of economic development; developing community welfare programs; absorption of the workforce; community economic empowerment; and realize access to capital; (4) Smart Living: a smart living environment for its inhabitants must be livable, comfortable, and safe, including: residential environment; business environment; healthy life through the availability of healthy food / drinks; health access; and the provision of transportation infrastructure that guarantees ease, comfort and affordable prices; (5) Smart Society: society is increasingly moving towards a socio-technical ecosystem where physical and virtual dimensions of life are more intensely intertwined, including: interactions in parallel between individuals; community and social groups; improving the quality of human resources; learning economy system; educational platform for the community; and management of security and safety for citizens; and (6) Smart Environment: giving impetus to other devices in the city to move to respond to the pollution that occurs, including: protection of land, water and air resources; green open space; river restoration; protecting the environment ecosystem; and utilize energy efficiently and responsibly.

Empirical research conducted by Pinochet, et al., (2018), titled the study Intention to live in a smart city based on its characteristics in the perception by the young public, shows the smart city model using dimensions, (1) economy, (2) people, (3) governance, (4) mobility, (5) environment, and (6) living. 


\section{Service Performance Concept (SERVPERF)}

The SERVPERF-SERVice Model Performance (Cronin \& Taylor 1992, 1994), is a derivative of the SERVQUAL model, but focuses on customer perceptions only on service performance. Many authors agree that customer ratings of services provided continually depend only on performance, so showing performance-based measures explains more differences in overall measures of service quality (Cronin \& Taylor, 1992).

Some researchers such as Babakus\&Boller (1992); Bolton \& Drew (1991); Brown et al. (1993); Carman (1990), has emphasized the need to use the SERVPERF scale developed by Cronin \& Taylor (1992). SERVPERF is one of the more important variants of the SERVQUAL scale, because it is based on components of performance perceptions that are conceptually and methodologically considered better than the SERVQUAL scale.

Methodologically, the SERVPERF scale shows a marked increase in the SERVQUAL scale. With a 50\% reduction in the number of items, this can explain the greater difference in overall service performance as measured through the use of a single item scale (Gotlieb et al., 1994; Hartline \& Ferrell, 1996; Woodruff et al., 1983). In this study service performance measurements (SERVPERF) are measured from opinions (Cronin \& Taylor, 1992, 1994), with measurement indicators, namely: (1) empathy, (2) reliability, (3) responsiveness, (4) assurance, (5) physical evidence.

Based on the theory and previous research, the hypotheses tested in this study are:

H1: Human capital influences the smart cityimplementation.

$\mathrm{H} 2$ : Human capital influences service performance.

H3: Smart city Implementation influences service performance.

H4: Human capital influences service performance through smart city implementation.

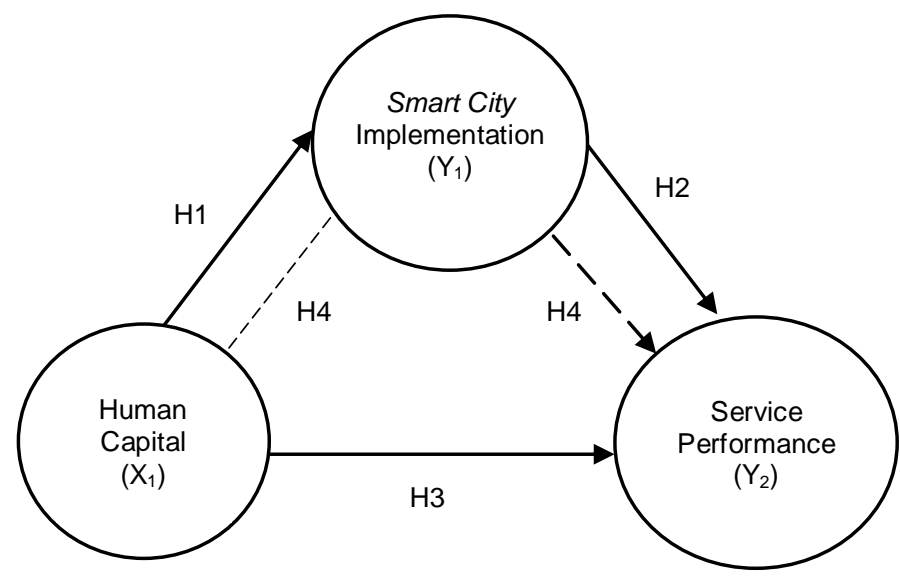

Figure 1:- Research Model.

$$
\begin{aligned}
\longrightarrow & =\text { Direct relationship } \\
---- & =\text { Indirect relationship }
\end{aligned}
$$

\section{Methodology Of Research:-}

This research used a quantitative research approach using primary data. Data were collected using questionnaires and interviews. This study used purposive sampling research, with research criteria namely smart city staff, and front-line service staff. Thus, information about gender, age, education level, and position is presented. Sample data $(\mathrm{n}=153)$, but only 51 respondents were processed. There was female dominance $(\mathrm{n}=81 ; 52.94 \%)$, marital status $(\mathrm{n}$ $=134 ; 87.58 \%)$, age range $35-45$ years $(n=57 ; 37.25 \%)$, education level Diploma/Bachelor $(n=78 ; 50.98 \%)$, work period $>15$ years $(n=75 ; 49.02 \%)$, front-line service staff positions $(n=59 ; 38.56 \%)$. 
Table 1:- Characteristics of Respondents.

\begin{tabular}{|c|c|c|}
\hline+2 & amount & Percentage \\
\hline \multicolumn{3}{|l|}{ Gender } \\
\hline Male & 72 & 47,06 \\
\hline Female & 81 & 52,94 \\
\hline Total & 153 & 100,00 \\
\hline \multicolumn{3}{|l|}{ Age } \\
\hline$<25$ & 19 & 12,42 \\
\hline $25-35$ & 47 & 30,72 \\
\hline $35-45$ & 57 & 37,25 \\
\hline$>45$ & 30 & 19,61 \\
\hline Total & 153 & 100.00 \\
\hline \multicolumn{3}{|l|}{ Education } \\
\hline Senior High School & 25 & 16,34 \\
\hline Diploma/Bachelor & 78 & 50,98 \\
\hline Magister & 45 & 29,41 \\
\hline Total & 153 & 10,00 \\
\hline \multicolumn{3}{|l|}{ Position } \\
\hline Staff/Operator Smart City & 54 & 35,29 \\
\hline StaffFront-Line Service & 59 & 38,56 \\
\hline Total & 153 & 100,00 \\
\hline
\end{tabular}

Source: Data processed

The human capital variable uses the instrument Felicio et al., (2014); Smart City implementation variable uses Ahmadjayadi, et al, (2016); Pinochet et al., (2018), service performance variables using the Cronin \& Taylor instrument $(1992 ; 1994)$ Research data were analyzed using structural equation modeling (SEM) with Partial Least Square (PLS) and then processed using the SmartPLS application version 3.2.8

\section{Results And Discussion:-}

Assessing the Outer Model or Measurement Model

There are at least 2 criteria in using data analysis techniques with SmartPLS to assess the outer model, convergent validity and composite reliability. The convergent validity of the measurement model with reflexive indicators is assessed based on the correlation between item scores/component scores estimated with SmartPLS software.

Individual reflexive measures are said to be high if they correlate more than 0.70 with the construct measured. But according to Chin, 1998 (in Ghozali\& Latan, 2015) for the initial stage of research the development of a measurement scale of loading factors of 0.5 to 0.6 is considered sufficient. In this research, a loading factor limit of 0.50 will be used.

Table 2:- Outer Loadings (Measurement Model).

\begin{tabular}{|c|c|c|c|}
\hline & Human Capital & Smart City Implementation & Service Performance \\
\hline X11 & 0.716 & & \\
\hline X12 & 0.818 & & \\
\hline X13 & 0.667 & & \\
\hline Y11 & 0.711 & 0.833 & \\
\hline Y12 & & 0.827 & \\
\hline Y13 & & 0.783 & \\
\hline Y14 & & 0.837 & \\
\hline Y15 & & 0.870 & 0.757 \\
\hline Y16 & & 0.823 & 0.872 \\
\hline Y21 & & & 0.876 \\
\hline Y22 & & & \\
\hline Y23 & & & \\
\hline
\end{tabular}




\begin{tabular}{|c|l|l|l|}
\hline Y24 & & & 0.861 \\
\hline Y25 & & & 0.803 \\
\hline
\end{tabular}

Source: Data processed

The results of processing using SmartPLS can be seen in Table 2. The outer model value or the correlation between constructs and variables has fulfilled convergent validity which indicates that all loading factors have values above 0.50 , so that constructs for all variables are not eliminated from the model.

\section{Evaluating Reliability and Average Variance Extracted (AVE)}

The reliability criteria can be seen from the reliability value of a construct and the value of the Average Variance Extracted (AVE) of each construct. The construct is said to have high reliability if the value is 0.60 and AVE is at the value of 0.50. In table 3 the Composite Reliability and AVE values are presented for all variables.

Table 3:- Composite Reliability and Average Variance Extracted.

\begin{tabular}{|c|c|c|c|}
\hline VARIABLE & COMPOSITEREIABIITY & $\begin{array}{c}\text { AVERAGEVARIANCE } \\
\text { EXTRACTED(AVE) }\end{array}$ & SQUAREAVE \\
\hline $\mathrm{X} 1$ & 0.819 & 0.533 & 0.730 \\
\hline $\mathrm{Y} 1$ & 0.930 & 0.688 & 0.829 \\
\hline $\mathrm{Y} 2$ & 0.920 & 0.697 & 0.835 \\
\hline
\end{tabular}

Source: Data processed

The AVE value for the latent variable $\mathrm{X} 1$ of 0.533 means that the latent variable $\mathrm{X} 1$ meets the requirements of conventional validity. This means that the latent variable already represents the indicators in the block. The AVE value for the Y1 latent variable of 0.688 means that the Y1 latent variable is approaching the convergent validity requirements. This means that the latent variable already represents the indicators in the block. The AVE value for the Y2 latent variable is 0.697 , which means that the Y2 latent variable meets the convergent validity requirements. This means that the latent variable already represents the indicators in the block.

The composite reliability value for the latent variable X1 was $0.819>$ standard reliability 0.6 . This has the purpose of measuring the internal consistency of latent variables above the standard value. The composite reliability value for the latent variable $\mathrm{Y} 1$ is $0.930>$ standard reliability 0.6 . This has the purpose of measuring the internal consistency of latent variables above the standard value. The composite reliability value for the latent variable Y2 is $0.920>$ standard reliability 0.6 . This has the purpose of measuring the internal consistency of latent variables above the standard value.

\section{Structural Model Testing (Inner Model):}

Measurement of inner model or structural model is done to see the relationship between construct, significance value and R-square of the research model. The structural model is evaluated using R-square for the dependent construct of the $t$ test as well as the significance of the coefficient of structural path parameters.

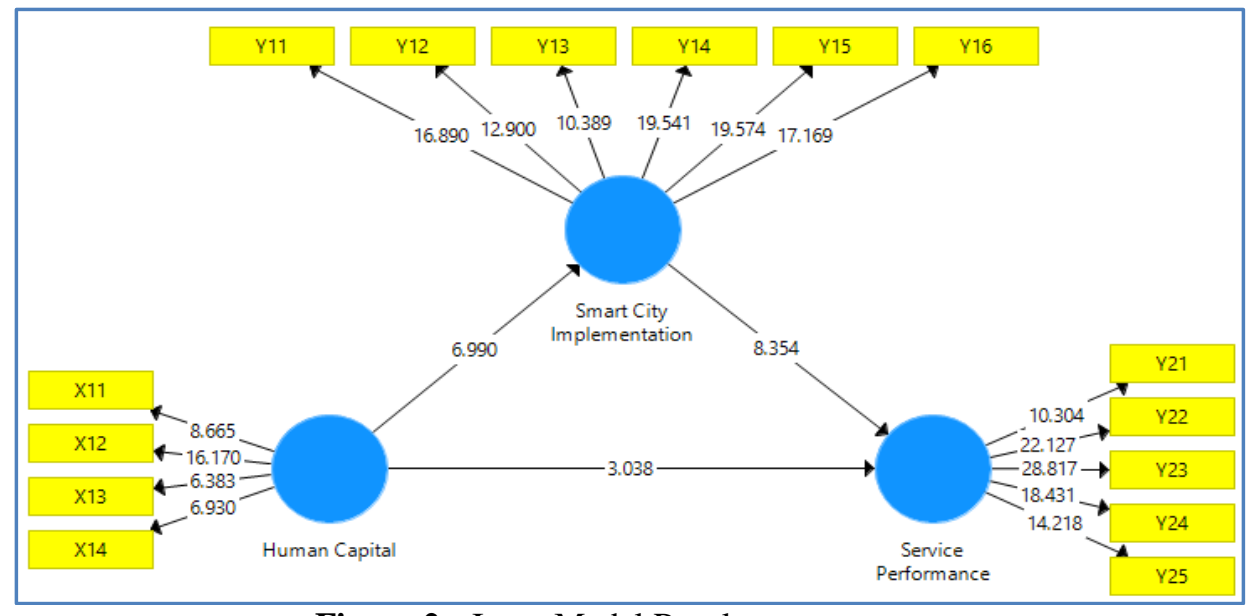

Figure 2:- Inner Model Results. 


\section{Hypothesis Testing Direct and Indirect Effects}

The basis used in testing hypotheses is the value contained in the output path coefficients. Table 4 gives the estimated output for testing structural models.

Table 4:- Test Results Hypothesis Direct and Indirect Effects.

\begin{tabular}{|c|l|c|c|c|}
\hline HYPOTHESIS & \multicolumn{1}{|c|}{ VARIABLERELATIONSHIP } & ORIGINALSAMPLE & $\begin{array}{c}\text { TSTATISTICS } \\
\text { (O/STDEV) }\end{array}$ & $\begin{array}{c}\text { P } \\
\text { VALUE }\end{array}$ \\
\hline H1 & $\mathrm{X} 1->\mathrm{Y} 1$ & 0.563 & 6.990 & 0.000 \\
\hline $\mathrm{H} 2$ & $\mathrm{X} 1-\mathrm{Y} 2$ & 0.262 & 3.038 & 0.001 \\
\hline $\mathrm{H} 3$ & $\mathrm{Y} 1-\mathrm{Y} 2$ & 0.654 & 8.354 & 0.000 \\
\hline $\mathrm{H} 4$ & $\mathrm{X} 1->\mathrm{Y} 1->\mathrm{Y} 2$ & 0.368 & 4.986 & 0.000 \\
\hline
\end{tabular}

Source: Data processed

Referring to the data from this study, human capital has a positive and significant effect on the smart city implementation. The path coefficient value found between the two variables is statistically significant, namely the path coefficient value of 0.563 with $t$ value of 6.990 or $p$-value of 0.000 . This value is greater than the t-table value $(1,675)$ or $\alpha<0.05$.

Human capital empirically has a positive and significant effect on service performance. The path coefficient value found between the two variables is statistically significant, namely the path coefficient value of 0.262 with a $t$ value of 3.038 or a p-value of 0.001 . This value is greater than $t$-table $(1,675)$ or $\alpha<0.05$.

The smart city implementation has a positive and significant effect on service performance. The path coefficient value found between the two variables is statistically significant, that is 0.654 with a t value of 8.354 or a p-value of 0.000 . This value is greater and $t$-table $(1,675)$ or $\alpha<0.05$.

Human capital has a positive and significant effect on service performance through the smart city implementation. The value of the coefficient of human capital path to the smart city implementation is 0.563 and significant, the smart city implementation on service performance is 0.654 and significant, then the effect of human capital on service performance is 0.262 and significant. The results of the examination provide evidence that the value of the direct influence path coefficient (smart city implementation) in explaining the effect of human capital on service performance is $0.368=0.563 \times 0.654$ and shows significant with a t value of $4.986>1,675$ and $p$-value of $0.000<0.05$.

\section{Conclusion:-}

Human capital has a positive and significant effect on the implementation of smart cities. The results of this study are accordance by De Noni et al., (2014) showing that the most important attribute that influences the ability of the city of Milan to attract talent is education. Likewise, a study conducted by Angelidou (2015) shows that in the context of human-centered smart cities, technological innovation encourages the development of human capital. The results of this study do not support the research of Klimovsky et al., (2016), that people do not want to use technology above the level of their needs and show little interest in participating in smart city governance issues. subsequently by Ferraris et al., (2018), different influences in managing social relations between internal and external employees involved in smart city projects. Parent \& Lovelace(2018), work involvement has no significant effect on individual abilities.

Human capital has a positive and significant effect on service performance (SERVPERF). The results of this study are accordance by Cooper et al., (1994), arguing that higher education levels are positively related to service performance. Important characteristics of human capital are education, experience and knowledge (Wrigth et al., 1995). A study conducted by Almurshidee, (2018), the significant impact of the quality of service (SERVPERF) of e-banking services found on customer satisfaction; reliability, certainty, and tangibility have the greatest influence on satisfaction. Also, the reliability and guarantee of e-banking services were found to have an effect on Word-ofMouth satisfaction. However, this study is not supported by Hatch \& Zweig (2000), assuming that no orientation pattern and cognitive behavior guarantee business success. several years of previous work experience did not have a significant impact on growth (Bruderl \& Preisendorfer, 2000). Mahmoud \& Khalifa, (2015), showed that Syrian university students have unfavorable beliefs about the service performance (SERVPERF) provided by the 
university. Additionally, support staff, in the eyes of students, are not responsive to provide timely assistance or show a high level of sympathy convincing in their interactions with students.

The smart city implementation has a positive and significant effect on service performance (SERVPERF). This research is in line with research by Yeh (2017), emphasizing that people are willing to accept and use ICT-based smart city services if the service is designed with an innovative concept that secures privacy and offers high-quality services. Empirical study by Akdere et al., (2018), shows that all dimensions of SERVPERF are significant predictors for overall service performance. Cho \& Hyun, (2016), show that interactivity and aesthetics positively influence perceived value because user satisfaction depends on aesthetics and reliability. findings by Mensah (2017) reinforce the results by suggesting that perceived ease of use, perceived quality of service, and public trust have a significant positive impact on people's intention to adopt and use e-government services. Instead this research is not supported by Paskaleva \& Cooper (2017), highlighting disappointment with the role and contribution of the community and other actors in the life cycle of production (management and evaluation of public services) smart city. Chouk \& Mani (2019), showed that consumer lifestyle factors reduce consumer resistance to smart services.

Human capital has a positive and significant effect on service performance (SERVPERF) through the smart city implementation. The results of this study are in line with research by Hatch \& Dyer (2004) showing that investment in corporate human capital has a significant impact on learning and company performance. Ushantha et al., (2014), consumers have a higher positive perception of the SERVPERF dimension. All dimensions significantly affect service performance. Felicio et al., (2014) show that human capital influences social capital, and that experience and cognitive abilities affect relationships and personal involvement. Instead this study is reciprocal with research Hatch \& Dyer (2004) showing that human capital with prior industry experience significantly reduces learning performance and that companies with high turnover significantly underperform under their rivals. Wang \& Chang (2005) shows that human capital indirectly influences performance through three other elements: innovation capital, process capital, and customer capital. Further findings by Kor \& Leblebici (2005) show that, although companies benefit from strategies and services with human capital and diversification strategies, the simultaneously strategies at a high level shows a negative effect on corporate profitability.

\section{References:-}

1. Ahmadjayadi, C., Subkhan, F., \&Wiradinata, M. R. 2016. MelesatatauKandas? New Indonesia dari Smart City menuju Smart Nation. Jakarta: Penerbit PT. Elex Media Komputindo.

2. Akdere, M., Top, M., \&Tekingunduz, S. 2018. Examining patient perceptions of service quality in Turkish hospitals: The SERVPERF model. Total Quality Management \& Business Excellence, 111.doi:10.1080/14783363.2018.1427501

3. Almurshidee, K., 2018. SERVPERF-based empirical evidence on e-banking services quality and customer satisfaction from Saudi banking sector. International Journal of Advanced and Applied Sciences, 5(11), Pages: 40-45. https://doi.org/10.21833/ijaas.2018.11.005

4. Analoui, F., \&Karami, A. 2003. Strategic management in small and medium enterprises. London: Thomson.

5. Angelidou, M.2015. Smart cities: A conjuncture of four forces. Cities, 47, 95-106. doi:10.1016/j.cities.2015.05.004

6. Ansoff, I. 1965. Corporate Strategy. New York: McGraw-Hill.

7. Armstrong, M. 2012. A Handbook of Human Resource Management Practice, (12th edn.), London, Kogan Page Publishers.

8. Babakus, E., \&Boller, G. W. 1992. An empirical assessment of the SERVQUAL scale. Journal of Business Research, 24(3), 253-268. doi:10.1016/0148-2963(92)90022-4

9. Babakus, E., \& Inhofe, M. 2014. Measuring Perceived Service Quality as a Multi-Attribute Attitude. Developments in Marketing Science: Proceedings of the Academy of Marketing Science, 376380.doi:10.1007/978-3-319-13159-7_86

10. BadanPusatStatistik. 2013. ProyeksiPenduduk Indonesia 2010-2035.

11. Bae, K.-J., \& Cha, S.-J. 2015. Analysis of the factors affecting the quality of service in public libraries in Korea. Journal of Librarianship and Information Science, 47(3), 173-186.doi:10.1177/0961000614532483

12. Barney, J. 1991. Firm Resources and Sustained Competitive Advantage. Journal of Management, Vol. 17 No. 1, 99-120.

13. Becker, G.S. 1964. Human Capital: A Theoretical and Empirical Analysis, with Special Reference to Education. University of Chicago Press, Chicago. 
14. Belanche, D., Casalo, L. V., \&Orús, C. 2016. City attachment and use of urban services: Benefits for smart cities. Cities, 50, 75-81.doi:10.1016/j.cities.2015.08.016

15. Bolton, R.N., \& Drew, J.H. 1991. A Longitudinal Analysis of the Impact of Service Changes on Customer Attitudes. Journal of Marketing, 55(1), 1. doi:10.2307/1252199

16. Brown, T. J., Churchill, G. A., \& Peter, J. P. 1993. Improving the measurement of service quality. Journal of Retailing, 69(1), 127-139. doi:10.1016/s0022-4359(05)80006-5

17. Bruderl, J., \&Preisendörfer, P. 2000. Fast-Growing Businesses. International Journal of Sociology, 30(3), 4570.doi:10.1080/15579336.2000.11770218

18. Carman, J.M. 1990. Consumer Perceptions of Service Quality: an Assessment of the SERVQUAL Dimensions, Journal of Retailing, Vol. 66, pp.33-55.

19. Caragliu, A., Del Bo, C. \&Nijkamp, P. 2009. Smart Cities in Europe. Proceedings of the 3rd Central European Conference in Regional Science - CERS 2009, Kosice, 7-9 October 2009, 49-59.

20. Chan, C.-S. 2018. Which city theme has the strongest local brand equity for Hong Kong: green, creative or smart city? Place Branding and Public Diplomacy.doi:10.1057/s41254-018-0106-x

21. Chandler, A.D. 1962. Strategy and Structure: Chapters in the History of American Enterprise. MIT Press, Boston.

22. Chatterjee, J. 2016. Strategy, human capital investments, business-domain capabilities, and performance: a study in the global software services industry. Strategic Management Journal, 38(3), 588608. doi:10.1002/smj.2505

23. Chatfield, A. T., \& Reddick, C. G. 2015. Smart City Implementation Through Shared Vision of Social Innovation for Environmental Sustainability. Social Science Computer Review, 34(6), 757-773. doi: $10.1177 / 0894439315611085$

24. Chi, C. G., \&Gursoy, D. 2009. Employee satisfaction, customer satisfaction, and financial performance: An empirical examination. International Journal of Hospitality Management, 28(2), 245253.doi:10.1016/j.ijhm.2008.08.003

25. Chin, W.W. 1998. The partial least squares approach for structural equation modeling. In G.A. Marcoulides (Ed). Modern methods for business research (pp. 295-336). London: Lawrence Erlbaum Associates.

26. Cho, C.-H., \& Hyun, J. H. 2016. What e-SERVPERF in recruiting websites does affect users' perceived value, satisfaction, and revisit intention in Korea? Total Quality Management \& Business Excellence, 118.doi:10.1080/14783363.2016.1188658

27. Chouk, I., \& Mani, Z. 2019. Factors for and against resistance to smart services: role of consumer lifestyle and ecosystem related variables. Journal of Services Marketing. doi:10.1108/jsm-01-2018-0046

28. Cooper, A. C., Gimeno-Gascon, F. J., \& Woo, C. Y. 1994. Initial human and financial capital as predictors of new venture performance. Journal of Business Venturing, 9(5), 371-395.doi:10.1016/0883-9026(94)90013-2

29. Costa, P.L., Passos, A.M., \& Bakker, A.B. 2014. Team work engagement: A model of emergence. Journal of Occupational and Organizational Psychology, 87(2), 414-436.doi:10.1111/joop.12057

30. Cronin, J.J. and Taylor, S.A. 1992. Measuring service quality: a reexamination and extension, Journal of Marketing, Vol. 56 No. 3, pp. 55-68.

31. Cronin J. J. and Taylor S. A. 1994. SERVPERF versus SERVQUAL: reconciling performance-based and perceptions-minus-expectations measurement of service quality. Journal of Marketing 58, 125-131.

32. De Noni, I., Orsi, L., \&Zanderighi, L. 2014. Attributes of Milan influencing city brand attractiveness. Journal of Destination Marketing \& Management, 3(4), 218-226.doi:10.1016/j.jdmm.2014.06.001

33. Edvinsson, L. \& Malone, M. 1997. Intellectual Capital: Realizing Your Company's True Value by Finding Its Hidden Brainpower. New York: Harper Collins.

34. Emerson, R. M. 1962. Power-Dependence Relations. American Sociological Review, 27(1), 31.doi:10.2307/2089716

35. Felicio, A., J., Couto, E., \&Caiado, J. 2014. Human capital, social capital and organizational performance. Management Decision, 52(2), 350-364. doi:10.1108/md-04-2013-0260

36. Ferraris, A., Santoro, G., Bresciani, S., \&Carayannis, E. G. 2018. HR practices for explorative and exploitative alliances in smart cities. Management Decision, 56(6), 1183-1197. doi:10.1108/md-04-2017-0384

37. Furrer, O., Thomas, H., \&Goussevskaia, A. 2008. The structure and evolution of the strategic management field: A content analysis of 26 years of strategic management research. International Journal of Management Reviews, 10(1), 1-23. doi:10.1111/j.1468-2370.2007.00217.x

38. Ghozali, I. \&Latan H. 2015. Partial Least Squares: Konsep, TeknikdanAplikasimenggunakanSmartPLS 3.0 untukpenelitianEmpiris. Semarang: BadanPenerbitanUniversitasDiponegoro. 
39. Goi, C.-L. 2017. The impact of technological innovation on building a sustainable city. International Journal of Quality Innovation, 3(1). doi:10.1186/s40887-017-0014-9

40. Gotlieb, J.B., Grewal, D., \& Brown, S.W. 1994. Consumer satisfaction and perceived quality: Complementary or divergent constructs? Journal of Applied Psychology, 79(6), 875-885. doi:10.1037/0021-9010.79.6.875

41. Hartline, M.D., \& Ferrell, O.C. 1996. The Management of Customer-Contact Service Employees: An Empirical Investigation. Journal of Marketing, 60(4), 52. doi:10.2307/1251901

42. Hatch, N. W., \& Dyer, J. H. 2004. Human capital and learning as a source of sustainable competitive advantage. Strategic Management Journal, 25(12), 1155-1178.doi:10.1002/smj.421

43. Hatch, J., \& Zweig, J. 2000. What is the stuff of an entrepreneur, Ivey Business Journal, Vol. 65 No. 2, pp. 68 72.

44. Hillman, A. J., Withers, M. C., \& Collins, B. J. 2009. Resource Dependence Theory: A Review. Journal of Management, 35(6), 1404-1427.doi:10.1177/0149206309343469

45. Hunger, J. D., \&Wheelen, T. L.. 2003. ManajemenStrategis (diterjemahkan: Agung, Julianto). Yogyakarta: PenerbitAndi.

46. Kadasah, N. A. 2017. An Evaluation of Service Quality of a Telecommunication Company in Saudi Arabia using SERVPERF Scale. International Review of Management and Business Research, Vol. 6, Issue.1. ISSN: 2306-9007. p. 162-171

47. Klimovsky, D., Pinteric, U., \&Saparniene, D. 2016. Human limitations To introduction of smart Cities: comparative analysis From two cee cities. Transylvanian Review of Administrative Sciences, No. 47, pp. 80-96

48. Kor, Y.Y., \&Leblebici, H. 2005. How do interdependencies among human-capital deployment, development, and diversification strategies affect firms' financial performance? Strategic Management Journal, 26(10), 967985. doi:10.1002/smj.485

49. Krusinskas, R., \&Bruneckienè, J. 2015. Measurement of intellectual capital of lithuanian cities by a composite index. Journal of Business Economics and Management, 16(3), 529-541.doi:10.3846/16111699.2012.729155

50. Kummitha, R. K. R., \&Crutzen, N. 2017. How do we understand smart cities? An evolutionary perspective. Cities, 67, 43-52. doi:10.1016/j.cities.2017.04.010

51. Lee, M. K. 2002. e-SERVQUAL: A scale for measuring consumer evaluations of internet service quality (in Korean). Marketing Research, 17(1), 73-95.

52. Le, P. T. \& Fitzgerald, G. 2014. Applying the SERVPERF Scale to evaluate Quality of Care in Two Public Hospitals at KhanhHoa Province, Vietnam. Asia Pacific Journal of Health Management, 9:

53. Mahmoud, A. B., \&Khalifa, B. 2015. A confirmatory factor analysis for SERVPERF instrument based on a sample of students from Syrian universities. Education + Training, 57(3), 343-359. doi:10.1108/et-04-20140038

54. Meijer, A. J., Gil-Garcia, J. R., \& Bolívar, M. P. R. 2015. Smart City Research. Social Science Computer Review, 34(6), 647-656. doi:10.1177/0894439315618890

55. Mensah, I. K. 2017. Citizens' Readiness to Adopt and Use E-government Services in the City of Harbin, China. International Journal of Public Administration, 41(4), 297-307.doi:10.1080/01900692.2016.1263658

56. Monica M.,\&Ramanaiah G. 2018. Service Quality Measurement at Brand Factory: An Empirical Study. Management and Labour Studies, 43(1-2), 70-77.doi:10.1177/0258042x17749650

57. Parasuraman, A., Zeithaml, V.A., \& Berry, L.L. 1988. SERVQUAL: a multiple-item scale for measuring consumer perceptions of service quality, Journal of Retailing, Vol. 64 No. 1, pp. 12-40.

58. Parent, J. D., \& Lovelace, K. J. 2018. Employee engagement, positive organizational culture and individual adaptability. On the Horizon. doi:10.1108/oth-01-2018-0003

59. Paskaleva, K. \& Cooper, I. 2017. Co-production and governance for smart city services: learning from practice: Editorial, International Journal of Services, Technology and Management, Special issue on Smart City and Service Innovation, Vol 23 (5/6): 1-12

60. Pfeffer, J. \&Salancik, G. 1978. The External Control of Organizations: A Resource Dependence Perspective. Harper \& Row, New York.

61. Pinochet, L. H. C., Romani, G. F., de Souza, C. A., \& Rodríguez-Abitia, G. 2018. Intention to live in a smart city based on its characteristics in the perception by the young public. Revista de Gestão.doi:10.1108/rege-062018-0077

62. Reddick, C. G. 2011. Citizen interaction and e - government. Transforming Government: People, Process and Policy, 5(2), 167-184. doi:10.1108/17506161111131195

63. Riffat, S., Powell, R., \&Aydin, D. 2016. Future cities and environmental sustainability. Future Cities and Environment, 2(0), 1. doi:10.1186/s40984-016-0014-2 
64. Schultz, T.W. 1961. Investment in Human Capital. American Economic Review, 51, 1-17. doi: https://www.jstor.org/stable/1818907

65. Sharma, S. K. 2015. Adoption of e-government services. Transforming Government: People, Process and Policy, 9(2), 207-222.doi:10.1108/tg-10-2014-0046

66. Siugzdiniene, J., Gaulè, E., \&Rauleckas, R. 2017. In search of smart public governance: the case of Lithuania. International Review of Administrative Sciences, 002085231770781.doi:10.1177/0020852317707814

67. Sohail, M. S., \& Jang, J. 2017. Understanding the relationships among internal marketing practices, job satisfaction, service quality and customer satisfaction: an empirical investigation of Saudi Arabia's service employees. International Journal of Tourism Sciences, 17(2), 67-85. doi:10.1080/15980634.2017.1294343

68. Supanto, F. 2019. ManajemenStrategiOrganisasiPublikdanPrivat. Malang: Empatdua Media.

69. United Nations, Department of Economic and Social Affairs, Population Division. 2015. World urbanization prospects: the 2014 Revision (ST/ESA/SER.A/366), ISBN 978-92-1-151517-6, available at: https://esa.un.org/unpd/wup/publications/files/wup2014-highlights.pdf (accessed 20 July 2018).

70. Unger, J. M., Rauch, A., Frese, M., \&Rosenbusch, N. 2011. Human capital and entrepreneurial success: A meta-analytical review. Journal of Business Venturing, 26(3), 341-358.doi:10.1016/j.jbusvent.2009.09.004

71. Ushantha, R.A. C., Wijeratne, A.W., \& Samantha, P.A.P. 2014. Customers' Perception on Service Quality towards Satisfaction: An Application of SERVPERF in State Sector Banks in Sri Lanka. European Journal of Business and Management. ISSN 2222-1905 (Paper) ISSN 2222-2839 (Online) Vol.6, No.4.

72. Wang, W., \& Chang, C. 2005. Intellectual capital and performance in causal models. Journal of Intellectual Capital, 6(2), 222-236.doi:10.1108/14691930510592816

73. Woodruff, R. B., Cadotte, E. R., \& Jenkins, R. L. 1983. Modeling Consumer Satisfaction Processes Using Experience-Based Norms. Journal of Marketing Research, 20(3), 296. doi:10.2307/3151833

74. Wright, P., Ferris, S. P., Hiller, J. S., \& Kroll, M. 1995. Competitiveness through management of diversity: effects on stock price valuation. Academy of Management Journal, 38(1), 272-287. doi:10.2307/256736

75. Yeh, H. 2017. The effects of successful ICT-based smart city services: From citizens' perspectives. Government Information Quarterly, 34(3), 556-565. doi:10.1016/j.giq.2017.05.001.

76. Yu, M., \& Hyun, S. S. 2019. The Impact of Foreign Flight Attendants' Service Quality on Behavioral Intention Toward Their Home Country-Applied SERVPERF Model. Sustainability, 11(15), 4136. doi:10.3390/su11154136. 